\title{
Analytical Application of DHOA for the Determination of Trace Metallic Constituents in Pu-based Fuel Materials by ICP-AES
}

\author{
Arijit Sengupta*, M.J. Kulkarni, S.V. Godbole, V. Natarajan, and P.N. Pathak \\ Radiochemistry Division, Bhabha Atomic Research Centre, \\ Trombay, Mumbai 400085, India
}

\section{INTRODUCTION}

The performance of fuel materials in a nuclear reactor to obtain desired burn-up depends on the physical and chemical composition and constituents of the fuel materials. Because of the high neutron absorption cross-section of $\mathrm{B}, \mathrm{Cd}$, $\mathrm{Eu}, \mathrm{Sm}, \mathrm{Gd}$, and Dy, there are stringent specification limits for fuel materials. In addition, elements that affect the physical properties of fuel, such as creep resistance, fuel density, sinterability, and hardness, also need to be monitored. Therefore, it is required to have critical quality control (both physical and chemical) of nuclear materials for their use in the reactor. Inductively coupled plasma atomic emission spectrometry (ICP-AES), which is a simultaneous, multi-elemental analytical technique with good precision and sensitivity, is regularly used for such purpose. However, the analytical technique based on ICP-AES suffers from spectral interferences. In particular, nuclear materials containing uranium, plutonium, and thorium due to their emission-rich spectra require a suitable separation procedure for removal of the major matrix without loss of analytes prior to their determination by ICP-AES. A number of separation procedures have been reported to achieve trace metal assay of nuclear materials (1-16). TBP (tri-n-butyl phosphate) has been used routinely for separation of the matrix prior to analysis. Some of the drawbacks associated with the use of TBP have been identified such as (a) non-incinera-

*Corresponding autbor.

arijita@barc.gov.in

\section{ABSTRACT}

DHOA (di-n-hexyl-octanamide) is one of the alternative extractants to TBP (tri-n-butyl phosphate), known for the extraction of plutonium from moderate nitric acid medium without significant extraction of the fission products. The analytical application of DHOA was explored to develop a methodology for the determination of trace metallic constituents in Pu-based nuclear materials. This involved the separation of the Pu matrix by $1.1 \mathrm{M}$ DHOA-dodecane, followed by the analysis of the raffinate for trace constituents by inductively coupled plasma atomic emission spectrometry (ICP-AES). A systematic study showed that five contacts of 1.1 M DHOA-dodecane were required for the quantitative extraction of $\mathrm{Pu}$ from $3 \mathrm{M} \mathrm{HNO}_{3}$ feed for a 1-g sample size in $10 \mathrm{~mL}$.

The feasibility of using DHOA for extraction of Pu from trace metallic constituents in Pu-based fuel materials without losing trace quantities of analytes of interest was studied by using synthetic samples after appropriate spiking of the common impurities and critical elements at their required specification limits (common elements: $5 \mathrm{ppm}$, critical elements: $1 \mathrm{ppm})$. A systematic study was carried out to compare the analytical performance of DHOA with TBP, which revealed that DHOA could successfully be employed for the determination of 19 trace constituents below the $5 \mathrm{ppm}$ limits for common elements. The stripping performance of DHOA was also found to be better in the recovery of Pu from the loaded organic phase. ble nature of the spent solvent yielding large volumes of secondary radioactive waste, (b) the deleterious nature of its degradation products (mainly $\mathrm{H}_{2} \mathrm{MBP}$ and $\mathrm{HDBP}$ ) affecting the separation and recovery, and (c) significant solubility of TBP towards the aqueous phase (17-19). In view of these drawbacks, a large number of eco-friendly $\mathrm{N}, \mathrm{N}$-dialkyl amides were explored as alternate extractants for the separation and recovery of nuclear materials from spent fuel containing minor actinides and long-lived fission products. Amongst these amides, dihexyloctanamide (DHOA) and di(2-ethylhexyl)-isobutyramide $\left(\mathrm{D}_{2} \mathrm{EHIBA}\right)$ received considerable attention as alternate potential extractants for the reprocessing of U- and Th-based spent nuclear fuels, respectively (20).

In order to determine the applicability of these novel extractants for analytical purposes, there is a need to ascertain that these materials can extract the major matrix without loss of impurities from the raffinate even at trace levels. In case of DHOA, the extraction behavior of Pu vis-a-vis a large number of elements of analytical interest have not been well investigated. In the present study, an attempt was made to explore the application of DHOA for the separation of $\mathrm{Pu}$ from trace analytes. The performance of DHOA was also compared with that of TBP. These investigations have shown that $1.1 \mathrm{M}$ DHOA/4 $\mathrm{M} \mathrm{HNO}_{3} /$ dodecane can be successfully used for the extraction of $\mathrm{Pu}$ from an aqueous acidic solution $\left(4 \mathrm{M} \mathrm{HNO}_{3}\right)$ to bring down the concentration of $\mathrm{Pu}$ in the raffinate below the tolerance level $(5 \mu \mathrm{g} / \mathrm{mL})$ without significant loss of the con- 
stituents even at the trace level. The methodology optimized in the present case was found to be useful for the determination of $12 \mathrm{com}$ mon impurities (CI) (Al, Ca, Co, Cr, $\mathrm{Cu}, \mathrm{Fe}, \mathrm{Mg}, \mathrm{Mn}, \mathrm{Na}, \mathrm{Ni}, \mathrm{Pb}, \mathrm{Zn}$ ) at 5 ppm, while seven critical elements (CE) (Ag, Eu, Sm, Gd, Dy, B, Cd) can be successfully determined at $1 \mathrm{ppm}$. Since the analytical performance of DHOA was found to be better than that of TBP, we propose that TBP can be replaced by DHOA, an environmentally benign incinerable extractant, for the determination of trace metallic constituents in a Pu matrix by inductively coupled plasma atomic emission spectrometry (ICP-AES).

\section{EXPERIMENTAL}

\section{Instrumentation}

All atomic emission spectroscopic studies were carried out using a Jobin-Yvon Ultima high resolution ICP-AES. It has the practical resolu- tion of $<0.005 \mathrm{~nm}$ and a spectral range of $200-800 \mathrm{~nm}$. The specifications and operating conditions of the instrument are listed in Table I.

\section{Standard Solutions and Reagents}

The standard solutions for rare earth and other common impurity elements were prepared from CertiPUR ${ }^{\circledR}$ ICP multi standard solutions (E. Merck, Darmstadt, Germany) by proper dilution with $0.5 \mathrm{M} \mathrm{HNO}_{3}$. Suprapur ${ }^{\circledR} \mathrm{HNO}_{3}$ (E. Merck, Darmstadt, Germany) and quartz doubly distilled water were used for making $0.5 \mathrm{M} \mathrm{HNO}_{3}$. Multi-point standardization was carried out using $0.5 \mathrm{M} \mathrm{HNO}_{3}$ as the lower standard and $0.05-1000 \mu \mathrm{g} / \mathrm{mL}$ of the corresponding elemental standard as the higher standards for each line after proper peak search. High purity $\mathrm{PuO}_{2}$ was taken to prepare the Pu standard stock solution.

TABLE I

Specifications and ICP-AES Operating Conditions

\begin{tabular}{ll}
\hline Spectrometer & \\
\hline Optical Design & $1 \mathrm{~m}$ Czerny Turner \\
Grating & Holographic, ion etched optical grating \\
Groove Density & 2400 grooves $/ \mathrm{mm}$ \\
Grating Size & $110 \times 110 \mathrm{~mm}$ \\
Wavelength Range & $120-800 \mathrm{~nm}$ \\
Band Pass & $0.0023 \mathrm{~nm}$ from $120-340 \mathrm{~nm}$ \\
& $0.0046 \mathrm{~nm}$ from $340-800 \mathrm{~nm}$ \\
Thermal Regulation & Controlled to $30 \pm 1^{\circ} \mathrm{C}$ \\
\hline RF Generator & \\
\hline Frequency & $40.68 \mathrm{MHz}$ \\
Oscillator & $27.12 \mathrm{MHz}$ \\
Pump & Dual channel $(12$ roller $)$ \\
Nebulizer & Cross flow and Ultrasonic type \\
\hline Operating Conditions & \\
\hline Ar Plasma Flow & $13 \mathrm{~L} / \mathrm{min}$ \\
Integration Time & $10 \mathrm{~s}$ \\
Reflected Power & $<10 \mathrm{~W}$ \\
Sample Rate & $1 \mathrm{ml} / \mathrm{min}$ \\
\hline
\end{tabular}

\section{Atomic Apectroscopy \\ Vol. 35(2), March/April 2014}

\section{Procedure}

Tracer studies were carried out with ${ }^{239} \mathrm{Pu}$ to understand the extraction behavior of $\mathrm{Pu}$ in the organic phase by using 30\% TBP-dodecane and 1.1 M DHOA-dodecane. The feed acidity was varied in the range of 1-6 $\mathrm{M} \mathrm{HNO}_{3}$. After two hours of equilibration, two phases were allowed to settle after appropriate centrifuging, followed by radiometric counting of suitable aliquots from the organic as well as the aqueous phase. A $100 \mathrm{mg} / \mathrm{mL}$ amount of Pu stock solution was prepared by dissolving appropriate amounts of high purity $\mathrm{PuO}_{2}$ in $\mathrm{HNO}_{3}$ medium. A $10-\mathrm{mL}$ amount of stock solution was allowed to equilibrate with 1.1 M DHOA in dodecane with aqueous:organic (1:1) for two hours. Five contacts of the organic phase were given and after each contact, suitable aliquots of raffinate were analyzed for residual $\mathrm{Pu}$. Similar studies were carried out using 30\% TBP-dodecane as the organic phase to compare the analytical results with that of DHOA. To establish the feasibility of $1.1 \mathrm{M}$ DHOA-dodecane for the separation of Pu without significant loss of impurities in the raffinate even at the trace level, studies were carried out using synthetic samples with appropriate amounts of added impurities. Five synthetic samples were prepared: (a) Pu blank (1 g of $\mathrm{Pu}$ dissolved in $10 \mathrm{~mL} 4 \mathrm{M} \mathrm{HNO}_{3}$ medium), (b) Sample-1 (Pu blank spiked with $50 \mathrm{ppm}$ of common impurities), (c) Sample-2 (Pu blank spiked with 5 ppm of common impurities), (d) Sample-3 (Pu blank spiked with $10 \mathrm{ppm}$ of critical elements), and (e) Sample-4 (Pu blank spiked with 1 ppm of critical elements). All samples were subjected to solvent extraction from $4 \mathrm{M}$ $\mathrm{HNO}_{3}$ feed using 1.1 M DHOA in dodecane as the organic phase with five contacts of A:O (1:1). After proper phase separation, the raffinates were analyzed by ICP-AES against multi-standards. The same 
exercise was repeated using 30\% TBP in dodecane as the organic phase for comparative study.

\section{RESULTS AND DISCUSSION}

To obtain optimum feed acid concentration for the effective extraction of $\mathrm{Pu}$, a systematic study was carried out at various feed acidities ranging from 1 to $6 \mathrm{M}$ $\mathrm{HNO}_{3}$. Figure 1 represents the extraction profiles of $\mathrm{Pu}$ at various feed acidities using 30\% TBP doecane and 1.1 M DHOA dodecane as the extracting systems. The study revealed that in the case of DHOA, the $\mathrm{DPu}$ value increases with an increase in feed acid molarity up to $3 \mathrm{M} \mathrm{HNO}_{3}$ followed by a plateau with $\mathrm{DPu} \sim 20$. The plateau at a higher feed acidity can be attributed to the competition of metal ions with hydronium ions $\left(\mathrm{H}_{3} \mathrm{O}^{+}\right)$ getting extracted into the organic phase. A similar extraction profile was also observed for Pu with TBP but with a lower DPu value $(\sim 10)$ as compared to DHOA at $3 \mathrm{M} \mathrm{HNO}_{3}$.

On the basis of the above study, the optimum acid concentration used in the feed solution was $3 \mathrm{M}$ $\mathrm{HNO}_{3}$ for the extraction of $\mathrm{Pu}$. Since the $\mathrm{D}$ value depends on the metal ion concentration in the feed, it is necessary to know the number of contacts required to bring the $\mathrm{Pu}$ level in the raffinate down to tolerable limits (less than $5 \mu \mathrm{g} / \mathrm{mL}$ ) in case of real samples. In view of this, a systematic study was carried out to determine the residual $\mathrm{Pu}$ after each contact of the organic phase with A:O (1:1). Table II represents the residual $\mathrm{Pu}$ in the raffinate after each contact with the organic phase, which suggested that four contacts of DHOA were required to bring the Pu concentration below tolerace limits as specified earlier, while five contacts can lead to quantitative removal of $\mathrm{Pu}$. For 30\% TBP, five contacts are sufficient to bring the $\mathrm{Pu}$ concentration down below the tolerance limit, while seven contacts are required for quantitative separation.

Based on the above experiments, it was decided to use five contacts of the organic phase for effective removal of $U$ from the aqueous phase. An increase in DPu value was found in case of DHOA as well as TBP with increase in the number of contacts of the organic phase. The above fact can be attributed to the decrease in $\mathrm{Pu}$ concentration in the feed solutions after each contact. The choice of suitable extractants for the separation of the

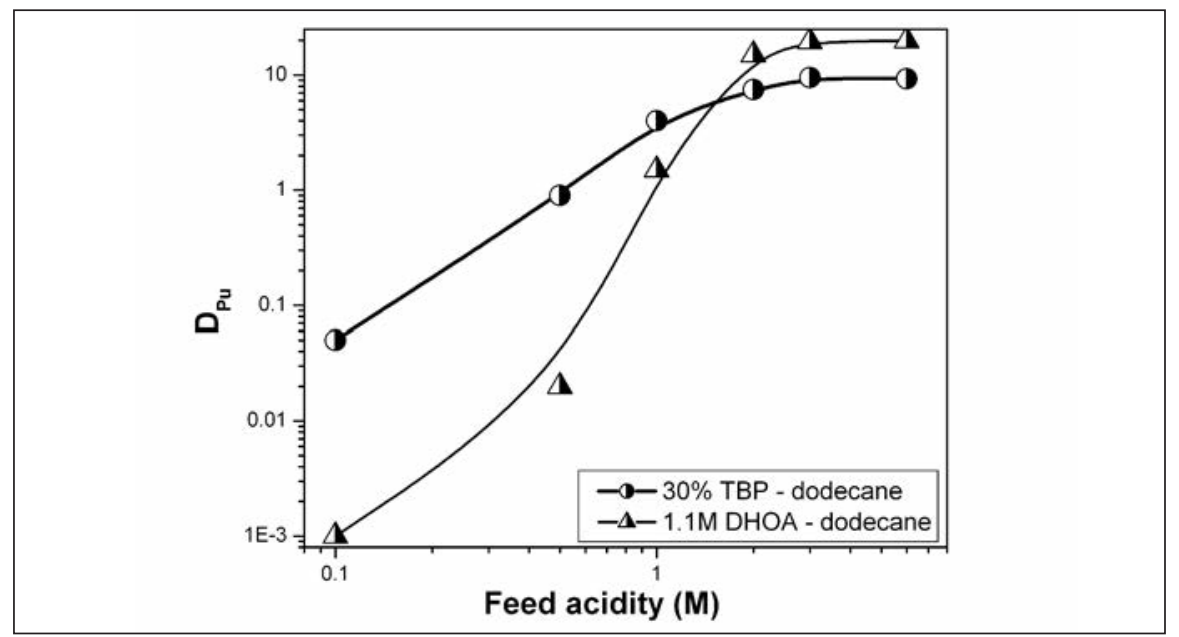

TABLE II

Residual Pu After Each Contact With Organic Base

\begin{tabular}{ccc}
\hline \multirow{2}{*}{$\begin{array}{c}\text { No. of } \\
\text { Contacts }\end{array}$} & \multicolumn{2}{c}{$\begin{array}{c}\text { Residual Pu in the } \\
\text { Raffinate }(\mu \mathrm{g} / \mathrm{mL})\end{array}$} \\
& $1.1 \mathrm{M}$ DHOA & $30 \% \mathrm{TBP}$ \\
\hline Initial Feed & 100,000 & 100,000 \\
1 & 5555 & 12500 \\
2 & 292 & 1453 \\
3 & 14 & 161 \\
4 & 0.73 & 17 \\
5 & 0.03 & 1.81 \\
6 & - & 0.18 \\
7 & - & 0.01 \\
\hline
\end{tabular}

Fig. 1. Extraction profile of Pu at various feed acidities using DHOA and TBP. 


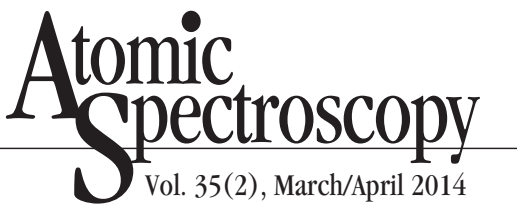

The analytical performance of DHOA was compared with that of TBP (Table V). It was found that DHOA is one of the alternative extractants to TBP for extraction of $\mathrm{Pu}$ into the organic phase to bring down the Pu concentration in the raffinate within the tolerable limit without significant loss of trace metallic constituents even at the trace level. The analytical performance of DHOA for the determination of trace metallic constituents in Pu-based fuel materials by ICPAES is found to be better than with TBP and is also environmentally benign, so DHOA is preferred for analytical application.

Stripping of loaded Pu from the TBP-dodecane system is one of the major problems faced by the analytical chemist. It was observed that even after six contacts of $0.5 \mathrm{M}$ $\mathrm{HNO}_{3}$ from an aqueous phase containing $100 \mathrm{mg} / \mathrm{mL}$ of $\mathrm{Pu}, 2 \mu \mathrm{g} / \mathrm{mL}$ $\mathrm{Pu}$ is left in the organic phase, while from DHOA, five contacts of $0.5 \mathrm{M} \mathrm{HNO}_{3}$ are more than enough for quantitative stripping of $\mathrm{Pu}$ (Table VI). Thus, not only is there a higher extraction ability, but the stripping behavior of DHOA is much more exciting than TBP.

\section{CONCLUSION}

A methodology was developed for trace metal assay of Pu-based fuel materials by ICP-AES using 1.1 M DHOA-dodecane for the chemical separation of uranium from the analytes. 1.1 M DHOA in dodecane was found to be the promising extractant for removal of $\mathrm{Pu}$ (five contacts, $\mathrm{A}: \mathrm{O}=1: 1$ ) leaving all other analytes of interest in the raffinate. The studies revealed that $5 \mathrm{ppm}$ of common impurities and $1 \mathrm{ppm}$ of critical elements can be determined in the Pu matrix by ICP-AES. A comparison of the analytical performance of DHOA with TBP revealed that its performance is better than that of TBP. According to the $\mathrm{C}, \mathrm{H}, \mathrm{O}, \mathrm{N}$ principle,
TABLE III

Determination of Common Elements in Synthetic Samples Using DHOA for Matrix Separation

\begin{tabular}{ccccc|ccc}
\hline Element & $\begin{array}{c}\text { Wave- } \\
\text { length } \\
(\mathrm{nm})\end{array}$ & $\begin{array}{c}\text { Amount } \\
\text { Added } \\
(\mu \mathrm{g} / \mathrm{mL})\end{array}$ & $\begin{array}{c}\text { Amount } \\
\text { Estimated } \\
(\mu \mathrm{g} / \mathrm{mL})\end{array}$ & $\begin{array}{c}\text { Recov- } \\
\text { ery } \\
(\%)\end{array}$ & $\begin{array}{c}\text { Amount } \\
\text { Added } \\
(\mu \mathrm{g} / \mathrm{mL})\end{array}$ & $\begin{array}{c}\text { Amount } \\
\text { Estimated } \\
(\mu \mathrm{g} / \mathrm{mL})\end{array}$ & $\begin{array}{c}\text { Recov- } \\
\text { ery } \\
(\%)\end{array}$ \\
\hline $\mathrm{Al}$ & 309.271 & 50 & $49 \pm 4$ & 98 & 5 & $5.2 \pm 0.4$ & 104 \\
$\mathrm{Ca}$ & 393.366 & 50 & $50 \pm 2$ & 100 & 5 & $5.1 \pm 0.5$ & 102 \\
$\mathrm{Co}$ & 238.892 & 50 & $47 \pm 4$ & 94 & 5 & $4.7 \pm 0.6$ & 94 \\
$\mathrm{Cr}$ & 283.563 & 50 & $49 \pm 2$ & 98 & 5 & $4.9 \pm 0.3$ & 98 \\
$\mathrm{Cu}$ & 224.7 & 50 & $51 \pm 2$ & 102 & 5 & $5.1 \pm 0.4$ & 102 \\
$\mathrm{Fe}$ & 259.94 & 50 & $49 \pm 3$ & 98 & 5 & $4.8 \pm 0.5$ & 96 \\
$\mathrm{Mg}$ & 279.553 & 50 & $53 \pm 4$ & 106 & 5 & $4.8 \pm 0.4$ & 96 \\
$\mathrm{Mn}$ & 257.61 & 50 & $48 \pm 2$ & 96 & 5 & $4.9 \pm 0.6$ & 98 \\
$\mathrm{Na}$ & 588.995 & 50 & $49 \pm 3$ & 98 & 5 & $5.1 \pm 0.3$ & 102 \\
$\mathrm{Ni}$ & 221.647 & 50 & $51 \pm 3$ & 102 & 5 & $5.2 \pm 0.4$ & 104 \\
$\mathrm{~Pb}$ & 220.353 & 50 & $50 \pm 4$ & 100 & 5 & $4.7 \pm 0.5$ & 94 \\
$\mathrm{Zn}$ & 213.856 & 50 & $48 \pm 4$ & 96 & 5 & $5.0 \pm 0.3$ & 100 \\
\hline
\end{tabular}

TABLE IV

Determination of Critical Elements in Synthetic Samples Using DHOA for Matrix Separation

\begin{tabular}{ccccc|ccc}
\hline Element & $\begin{array}{c}\text { Wave- } \\
\text { length } \\
(\mathrm{nm})\end{array}$ & $\begin{array}{c}\text { Amount } \\
\text { Added } \\
(\mu \mathrm{g} / \mathrm{mL})\end{array}$ & $\begin{array}{c}\text { Amount } \\
\text { Estimated } \\
(\mu \mathrm{g} / \mathrm{mL})\end{array}$ & $\begin{array}{c}\text { Recov- } \\
\text { ery } \\
(\%)\end{array}$ & $\begin{array}{c}\text { Amount } \\
\text { Added } \\
(\mu \mathrm{g} / \mathrm{mL})\end{array}$ & $\begin{array}{c}\text { Amount } \\
\text { Estimated } \\
(\mu \mathrm{g} / \mathrm{mL})\end{array}$ & $\begin{array}{c}\text { Recov- } \\
\text { ery } \\
(\%)\end{array}$ \\
\hline $\mathrm{Ag}$ & 328.068 & 10 & $10.0 \pm 0.3$ & 100 & 1 & $1.07 \pm 0.04$ & 107 \\
$\mathrm{Eu}$ & 420.505 & 10 & $9.8 \pm 0.4$ & 96 & 1 & $1.2 \pm 0.3$ & 120 \\
$\mathrm{Sm}$ & 359.262 & 10 & $9.7 \pm 0.2$ & 94 & 1 & $0.98 \pm 0.1$ & 98 \\
$\mathrm{Gd}$ & 342.247 & 10 & $10.1 \pm 0.5$ & 102 & 1 & $0.97 \pm 0.04$ & 97 \\
$\mathrm{Dy}$ & 353.17 & 10 & $10.0 \pm 0.5$ & 100 & 1 & $0.99 \pm 0.05$ & 99 \\
$\mathrm{~B}$ & 249.773 & 10 & $9.9 \pm 0.4$ & 98 & 1 & $1.1 \pm 0.05$ & 110 \\
$\mathrm{Cd}$ & 228.802 & 10 & $10.2 \pm 0.9$ & 104 & 1 & $0.98 \pm 0.10$ & 98 \\
\hline
\end{tabular}

unlike TBP, DHOA is an incinerable, environmentally benign extractant. Therefore, it can be applied satisfactorily for removal of the $\mathrm{Pu}$ matrix, followed by the determination of trace metallic constituents in the raffinate by ICP-AES. The performance of DHOA was also found to be better than TBP to strip back the Pu-loaded organic phase by using $0.5 \mathrm{M} \mathrm{HNO}_{3}$.

Received September 2, 2013. 
TABLE V

Analytical Data Obtained for Synthetic Samples Using TBP and DHOA for Matrix Separation

\begin{tabular}{|c|c|c|c|}
\hline \multirow[t]{2}{*}{ Elements } & \multirow{2}{*}{$\begin{array}{l}\text { Pu Blank } \\
\text { (ppm) }\end{array}$} & \multicolumn{2}{|c|}{ Pu Blank + 5 ppm CI + 1 ppm CE (ppm) } \\
\hline & & 1.1M DHOA & $30 \%$ ТВР \\
\hline $\mathrm{Cr}$ & 0.3 & 5.5 & 4.7 \\
\hline $\mathrm{Zn}$ & 2.9 & 8.3 & 7.1 \\
\hline $\mathrm{Pb}$ & 0.5 & 5.2 & 5.3 \\
\hline $\mathrm{Cd}$ & $<0.05$ & 1.1 & 0.96 \\
\hline $\mathrm{Ni}$ & 0.2 & 5.3 & 5.6 \\
\hline Co & $<0.05$ & 4.8 & 4.8 \\
\hline B & 0.18 & 1.3 & 0.7 \\
\hline Mn & 0.1 & 4.9 & 5.3 \\
\hline $\mathrm{Fe}$ & 2.2 & 7.1 & 7.2 \\
\hline $\mathrm{Mg}$ & 0.8 & 5.9 & 6 \\
\hline $\mathrm{Al}$ & 1.7 & 7 & 6.8 \\
\hline $\mathrm{Cu}$ & 0.1 & 4.9 & 5.2 \\
\hline $\mathrm{Ag}$ & $<0.05$ & 0.99 & 1.2 \\
\hline Gd & $<0.05$ & 0.97 & 1.1 \\
\hline Dy & $<0.05$ & 1.12 & 0.97 \\
\hline $\mathrm{Sm}$ & $<0.05$ & 1.03 & 0.99 \\
\hline Eu & $<0.05$ & 1.2 & 0.97 \\
\hline $\mathrm{Ca}$ & 4 & 9.2 & 8.8 \\
\hline $\mathrm{Na}$ & 3.2 & 8.1 & 8.4 \\
\hline
\end{tabular}

TABLE VI

Stripping Study of the Pu-loaded Organic Phase

\begin{tabular}{ccc}
\hline \multirow{2}{*}{$\begin{array}{c}\text { No. of Contacts } \\
\text { of } 0.5 \mathrm{M} \mathrm{HNO}_{3}\end{array}$} & \multicolumn{2}{c}{ Residual Pu in the Organic Phase $(\mu \mathrm{g} / \mathrm{mL})$} \\
\hline From $1.1 \mathrm{M} \mathrm{DHOA}$ & From $30 \% \mathrm{TBP}$ \\
\hline Initial Loaded Organic & 100,000 & 100,000 \\
1 & 6000 & 16,666 \\
2 & 240 & 2777 \\
3 & 7.2 & 462 \\
4 & 0.14 & 77 \\
5 & 0.003 & 12 \\
6 & - & 2.1 \\
\hline
\end{tabular}

\section{REFERENCES}

1. M. Gopalkrishnan, K. Radhakrishnan, P.S. Dhami, V.T. Kulkarni M.V. Joshi, A.B. Patwardhan, A. Ramanujam, and J.N. Mathur, Talanta 44(2), 169(1997).

2. K. Satyanarayana and S. Durani, J. Radioanal. Nucl. Chem. 285(3), 659 (2010).
3. P.L. Mahanta, G. Chakrapani and R. Radhamani, At. Spectrosc. 31(1), 21 (2010).

4. S. Chandramouleeswaran and J.C. Upadya, Explor. Res. At. Miner 19, 54 (2009)

5. W.Y. Liu and S.L. Zeng, Yuanzineng Kexue Jishu/At. Energy Sci. Technol. 38(5), 424 (2004).

6. B. Rajeswari, B.A. Dhawale, T.R. Bangia, J.N. Mathur and A.G. Page, J. Radioanal. Nucl. Chem. 254(3), 479 (2002).

7. A.A. Argekar, M.J. Kulkarni, J.N. Mathur and A.G. Page, Talanta 56(4),.591 (2002).

8. C. Mahan, S. Bonchin, D. Figg, D. Gcrth and C. Collier, J. Anal. At. Spectrom.15(8), 929 (2000).

9. R.K. Malhotra and K. Satyanarayana, Talanta 50(3), 601 (1999).

10. S.G. Johnson, J.J. Giglio and P.S. Goodall, Cummings Proceedings of SPIE, The International Society for Optical Engineering 3270, 158 (1998).

11. S. Marin, S. Cornejo, C. Jara and N. Duran, Fresenius' J. Anal. Chem. 355(5-6), 680 (1996).

12. E.A. Huff, At. Spectrosc. 42(1-2), 275 (1987).

13. P.J. Purohit, N. Goyal, S.K. Thulasidas, A.G. Page and M.D. Sastry, Spectrochim. Acta Part B 55(8), 1257 (2000).

14. E.A. Huff and D.L. Bowers, Appl. Spectrosc .43(2), 223 (1989).

15. R. Ko, Appl. Spectrosc. 38, 909 (1984).

16. C Mahan, S. Bonchin, D. Figg, D. Gerth and C. Collier, J. Anal. Spectrom. 15, 929 (2000).

17. P.N. Pathak, L.B. Kumbhare and V.K. Manchanda, Radiochim. Acta 89(7), 44 (2001).

18. V.K. Manchanda and P.N. Pathak, Sep. Purif. Technol. 35, 85 (2004).

19. P.N. Pathak, D.R. Prabhu, A.S. Kanekar and V.K. Manchanda, Mater. Sci. Eng. 9, 1 (2010).

20. P.B. Ruikar, M.S. Nagar, M.S. Subramanian, K.K. Gupta, N. Varadarajan and R.K. Singh, J. Radioanal. Nucl. Chem. 196, 171 (1995). 